\title{
EFEKTIVITAS FUNGISIDA BAHAN AKTIF MANKOZEB UNTUK MENGENDALIKAN HAWAR DAUN KENTANG (Phytopthora infestans) DI SUMBER BRANTAS DAN NONGKOJAJAR
}

\author{
Riza Ulil Fitria ${ }^{1)}$ dan Diding Rachmawati ${ }^{1)}$ \\ ${ }^{1)}$ Balai Pengkajian Teknologi Pertanian Jawa Timur, Malang \\ Email: riza_bptp@yahoo.com
}

\begin{abstract}
ABSTRAK
Tujuan penelitian untuk mengetahui tingkat efektivitas fungisida berbahan aktif mankozeb $80 \%$ terhadap serangan patogen Phythopthora infestans pada kentang. Penelitian dilaksanakan di Desa Sumberbrantas, Kota Batu pada Oktober-Desember 2017 dan di Nongkojajar Kabupaten Pasuruan pada FebruariApril 2018. Penelitian menggunakan Rancangan Acak Kelompok dengan 5 ulangan. Perlakuan terdiri dari a). Mankozeb 80\% 4g/l; b). Mankozeb 80\% 3g/l; c). Mankozeb $80 \% 2 \mathrm{~g} / \mathrm{l}$; d). Mankozeb $80 \%$ konsentrasi $1 \mathrm{~g} / \mathrm{l}$; dan e). Kontrol (tanpa perlakuan). Hasil penelitian menunjukkan bahwa di lokasi SumberbrantasBatu, Mankozeb 80\% $3 \mathrm{~g} / \mathrm{l}$ dan $4 \mathrm{~g} / \mathrm{l}$ efektif terhadap penyakit hawar daun kentang $(P$. insfestans) pada tanaman kentang dengan kemampuan menekan serangan masing-masing sebesar $66,58 \%$ dan $77,99 \%$, dengan produksi kentang berturut-turut 6,9 ton/ha dan 7,9 ton/ha. Di lokasi Nongkojajar-Pasuruan, fungisida mankozeb $80 \% 4 \mathrm{~g} / \mathrm{l}, 3 \mathrm{~g} / \mathrm{l}$ dan $2 \mathrm{~g} / \mathrm{l}$ mampu menekan serangan berturutturut sebesar $61,65 \%, 45,68 \%$ dan $42.18 \%$ terhadap penyakit hawar daun kentang $P$. infestans, dan produksi kentang berturut-turut 6,03 ton/ha, 5,13 ton/ha, dan 5,49 ton/ha.
\end{abstract}

Kata kunci: efektivitas; fungisida; hawar daun; kentang; Phythopthora insfestans

\section{ABSTRACT}

This research is to find out the effectiveness of $80 \%$ mankozeb active ingredient on the attack of pathogen Phythopthora infestans on potatoes. This research was conducted at village of Sumberbrantas, Batu on October-December 2017 and at Nongkojajar Pasuruan Regency on February-April 2018. The study used Randomized Block Design with 5 replications. The treatments consisted of a). Mankozeb 80\% 4g/l; b). Mankozeb 80\% 3g/l; c). Mankozeb 80\% 2 g/l;d). Mankozeb $80 \% 1 \mathrm{~g} / \mathrm{l}$; and e. Control (without Mankozeb). The results showed that at Sumberbrantas-Batu, Mankozeb $80 \% 3 \mathrm{~g} / \mathrm{l}$ and $4 \mathrm{~g} / \mathrm{l}$ were effective against potato leaf blight (P. insfestans) on potato plants with the ability to suppress attacks respectively $66.58 \%$ and $77.99 \%$, and potato production respectively 6.9 tons/ha and 7.9 tons/ ha. At Nongkojajar-Pasuruan, the mankozeb $80 \% 4 \mathrm{~g} /$, $3 \mathrm{~g} / \mathrm{l}$ and $2 \mathrm{~g} / \mathrm{l}$ were able to suppress attacks successively at $61.65 \%, 45.68 \%$ and $42.18 \%$ against $P$. infestans potato leaf blight,and the production were 6.03 tons/ha, 5.13 tons/ha, and 5.49 tons/ha.

Keywords: effectiveness; fungicide; leaf blight; Phythopthora insfestas; potato 


\section{PENDAHULUAN}

Kentang merupakan salah satu pangan utama dunia setelah padi, gandum, dan jagung. Disamping itu, kentang termasuk salah satu komoditas hortikultura yang mempunyai nilai perdagangan domestik dan potensi eksport yang cukup baik. Produksi kentang di Indonesia pada tahun 2010 mencapai 1.060.579 ton dengan produktivitas 15,95 ton/ha. Hal ini menurun jika dibandingkan dengan produksi dan produktivitas kentang pada tahun 2009, yaitu 1.176 .304 ton dan 16,51 ton/ha (BPS, 2009).

Sentra produksi kentang Indonesia berada di Jawa Barat, Jawa Tengah, Jawa Timur dan Sumatera Utara. Di Jawa Timur, sentra produksi kentang berada di Kota Batu dan Kabupaten Pasuruan.

Produksi kentang di Indonesia hanya dapat memenuhi $10 \%$ konsumsi kentang nasional yaitu 8,9 juta/tahun. Langkanya ketersediaan kentang pun mengakibatkan pengembangan industri potato chips di Indonesia masih tertinggal (Puslitbang Hortikultura, 2008).

Upaya peningkatan produksi kentang menghadapi berbagai kendala. Salah satunya adalah serangan patogen tanaman. (Jeger, dkk, 1996; dan Hanm, 2007). Hal ini ditunjukkan dengan seringnya dijumpai penyakit pada tiap musim tanam, sehingga produksi kentang tidak maksimal. Penyakit yang menyerang sebagian besar akibat patogen yang bersifat tular tanah yang mampu hidup, menyebar, dan bertahan dalam jangka waktu yang lama di dalam tanah (Jeger, dkk., 1996; dan Hanm, 2007).

Patogen tular tanah utama yang sering dijumpai dan sangat merugikan di pertanaman kentang antara lain Phythopthora infestans (Jeger, dkk., 1996; dan Elphinste, 2007). Patogen P. infestans menyerang kentang yang ditanam di dataran tinggi $(1200 \mathrm{~m})$ di atas permukaan laut (Semangun, 2006; dan Priou, dkk., 2011). Kehilangan hasil yang diakibatkan $P$. infestans berkisar 47-100\% (Dinar, dkk., 2011).

Umumnya gejala serangan penyakit mulai muncul pada tanaman yang berumur lebih dari satu bulan. Gejala pertama adalah terlihatnya bercak nekrotis coklat yang dimulai dari tepi daun. Pada cuaca kering 
bercak tidak meluas, tetapi pada kondisi sering hujan, berkabut, dan lembab nekrotis meluas dengan cepat dan mematikan daun. Gejala lainnya adalah pada sisi bawah daun terlihat lapisan kelabu tipis terdiri dari konidiofor dan konidium jamur (Semangun, 2000). Bahkan kalau cuaca demikian berlangsung lama, batang utama akan terserang atau seluruh bagian tanaman atas akan mati.

$$
\begin{aligned}
& \text { Kenyataan di rapangan } \\
& \text { menunjukkan bahwa kentang } \\
& \text { Varietas Granola yang ditanam di } \\
& \text { dataran tinggi Sumber Brantas selalu } \\
& \text { terserang hawar daun dari tahun ke } \\
& \text { tahun terutama pada musim hujan } \\
& \text { antara Bulan September sampai }
\end{aligned}
$$
Januari. Kondisi ini terjadi pada kebun yang diberi aplikasi fungisida secara intensif bahkan sering melebihi konsentrasi anjuran.

Penelitian ini akan menguji efikasi fungisida Mankozeb 80 WP yang berbahan aktif mankozeb $80 \%$ dengan interval 7 hari sekali untuk mengendalikan serangan patogen $P$. infestans pada kentang di Sumber Brantas dan Nongkojajar.

\section{METODE PENELITIAN}

Penelitian dilaksanakan di Desa Sumberbrantas, Kota Batu mulai Bulan Oktober-Desember 2017 dan di desa Nongkojajar, Kabupaten Pasuruan mulai bulan Februari-April 2018. Rancangan yang digunakan adalah Rancangan Acak Kelompok terdiri dari :

a) Mankozeb $80 \% 4 \mathrm{~g} / \mathrm{l}$

b) Mankozeb $80 \% 3 \mathrm{~g} / \mathrm{l}$

c) Mankozeb $80 \% 2 \mathrm{~g} / 1$

d) Mankozeb $80 \% 1 \mathrm{~g} / \mathrm{l}$

e) Kontrol (tanpa fungisida)

Analisis dilakukan untuk mengetahui pengaruh perlakuan dengan menggunakan analisis varian (ANOVA) dan apabila ada pengaruh, maka dilakukan uji BNJ dengan $\alpha=$ $5 \%$.

Intensitas serangan patogen dihitung menggunakan rumus Correa, dkk. (2008) dengan skala serangan sebagai berikut.

0 : Tidak ada serangan

1 : Kerusakan antara 1-12\%

2 : Kerusakan antara 12-22\%

3 : Kerusakan antara $22-40 \%$

4 : Kerusakan antara 40-77\%

5 : Kerusakan antara $77-100 \%$ 
Aplikasi

fungisida

menggunakan alat semprot punggung semi otomatis. Pengamatan pertama sebelum aplikasi dilakukan saat tanaman sudah berjumlah 3-4 daun. Kemudian satu minggu setelah pengamatan pertama dilakukan aplikasi penyemprotan dengan interval 1 minggu sekali sebanyak 7 kali aplikasi. Pengamatan intensitas serangan penyakit dilakukan dengan interval satu minggu sekali.

Parameter keefektifan fungisida dihitung rumus Abbott (Sugama dan Rochjadi, 1989). Keefektivan fungisida dinilai dengan kategori sebagai berikut: $0=$ tidak efektif , $>0-20 \%=$ sangat kurang efektif, $>20-40 \%=$ kurang efektif, $>40-60 \%=$ cukup efektif, $>60-80 \%$ $=$ efektif, dan $>80 \%=$ sangat efektif (Irasakti dan Sukatsa, 1987).

\section{HASIL DAN PEMBAHASAN}

\section{Hasil Pengamatan Lokasi Sumberbrantas Batu}

Gejala awal yang ditimbulkan oleh penyakit hawar daun pada susunan daun terbawah terlihat adanya noda berwarna cokelat menghitam pada ujung dan sisi daun, kemudian pada bagian bawah daun terlihat adanya spora yang berwarna putih (Gambar 1).

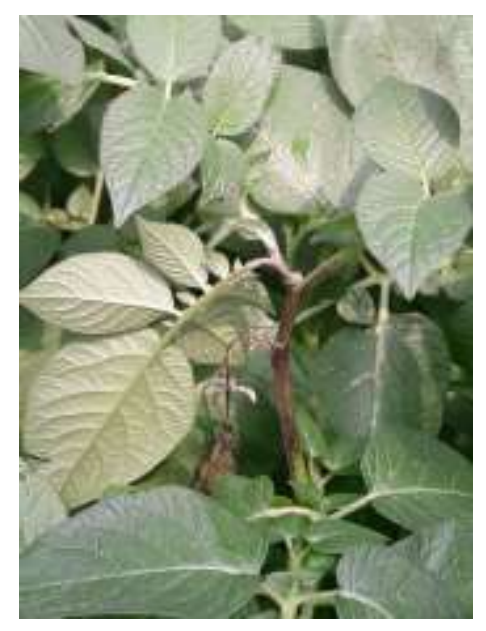

Gambar 1. Gejala awal pada daun

Pada kondisi serangan berat, gejala tidak hanya menyerang daun bahkan batang tanaman pun menjadi hitam kecokelatan dan batang menjadi patah (Gambar 2).
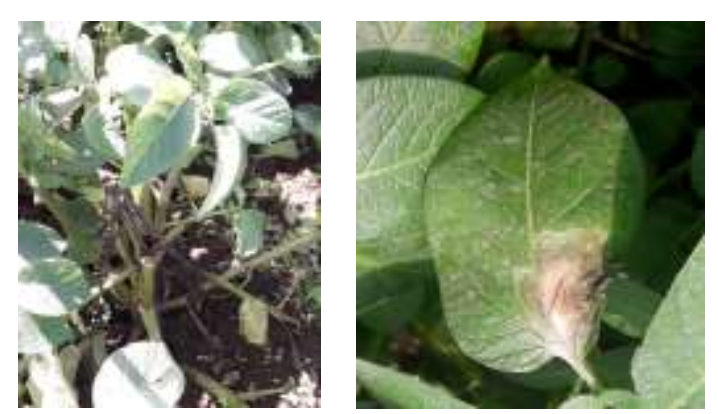

Gambar 2. Gejala menyebabkan batang patah

Pengaruh beberapa konsentrasi fungisida Mankozeb 80 WP terhadap intensitas serangan penyakit hawar daun P.infestans pada umur 21-56 HST. disajikan pada Tabel 1. 
Tabel 1. Intensitas Serangan P. infestans (\%) di Sumberbrantas Batu pada Musim Hujan 2017

\begin{tabular}{|c|c|c|c|c|c|c|c|}
\hline \multirow{2}{*}{$\begin{array}{l}\text { Perlakuan } \\
\text { Mankozeb }\end{array}$} & \multicolumn{7}{|c|}{$\begin{array}{c}\text { Intensitas serangan } P . \text { infestans }(\%) \\
\text { Hari Setelah Tanam (HST) }\end{array}$} \\
\hline & 21 & 28 & 35 & 42 & & 49 & 56 \\
\hline a. $4 \mathrm{~g} / \mathrm{l}$ & $2,8 \mathrm{a}$ & $12,6 \mathrm{a}$ & $6,4 \mathrm{a}$ & $4,8 \mathrm{a}$ & $6,4 \mathrm{a}$ & $7,0 \mathrm{a}$ & 7,4 \\
\hline b. $3 \mathrm{~g} / 1$ & $3,6 \mathrm{a}$ & $7,2 \mathrm{a}$ & $12,8 \mathrm{a}$ & $11,2 \mathrm{~b}$ & $12,8 \mathrm{a}$ & $21,6 \mathrm{~b}$ & 13,1 \\
\hline c. $2 \mathrm{~g} / \mathrm{l}$ & $10,4 \mathrm{~b}$ & $12,0 \mathrm{a}$ & $23,2 \mathrm{~b}$ & $14,4 \mathrm{~b}$ & $20,0 \mathrm{~b}$ & $24,0 \mathrm{~b}$ & 18,7 \\
\hline d. $1 \mathrm{~g} / 1$ & $16,0 \mathrm{c}$ & $12,8 \mathrm{a}$ & $28,0 \mathrm{ab}$ & $23,6 \mathrm{c}$ & $32,0 \mathrm{c}$ & $35,2 \mathrm{c}$ & 26,3 \\
\hline e. Kontrol & $14,4 \mathrm{bc}$ & $25,2 \mathrm{~b}$ & $36,4 \mathrm{c}$ & $37,2 \mathrm{~d}$ & $38,0 \mathrm{c}$ & $55,2 \mathrm{~d}$ & 38,4 \\
\hline
\end{tabular}

Keterangan: Angka yang diikuti huruf yang sama pada kolom menunjukkan tidak berbeda nyata berdasarkan Uji BNJ dengan $\alpha=5 \%$.

HST $=$ hari setelah tanam

Pada tabel 1 dapat dilihat bahwa intensitas serangan $P$. infestans sejak umur 21 HST terus meningkat dengan meningkatnya umur tanaman. Peningkatan serangan $P$. infestans pada tanaman yang mendapat perlakuan fungisida tidak secepat perlakuan kontrol (tanpa fungisida). Pada 28 HST perlakuan a dan $b$ tidak berbeda nyata dengan tingkat serangan $2,8 \%$ dan $3,6 \%$, namun berbeda nyata dengan perlakuan c, d, dan e yaitu $10,4 \%$, $16 \%$, dan 14\%. Selanjutnya pada pengamatan 35 HST, perlakuan a, b, c, dan d tidak berbeda pada masingmasing perlakuan, namun berbeda nyata dengan perlakuan e.

Pada 42 HST, perlakuan a dan bB berbeda nyata dengan tingkat serangan sebesar $4,8 \%$ dan $11,2 \%$, namun tidak berbeda nyata dengan perlakuan $\mathrm{c}, \mathrm{d}$, dan e masing-masing sebesar 14,4\%, 23,6\%, dan 37,2\%. Pada 49 HST dan 56 HST, perlakuan a tingkat serangan tetap rendah dan berbeda nyata dengan perlakuan lainnya. Dari hasil rata-rata intensitas serangan penyakit hawar daun $P$. infestans terlihat bahwa pada perlakuan a serangannya adalah yang terendah yaitu $7.44 \%$, sedangkan serangan tertinggi perlakan e sebesar 38.4\%. Hal ini dikarenakan perlakuan a dengan konsentrasi tinggi yaitu 4 g/l mampu menekan intensitas serangan $P$. infestans. Menurut Suhardi (2007) fungisida mampu menekan perkembangan penyakit pada tanaman yang diakibatkan oleh fungi. Pada serangan yang tinggi, semakin tinggi 
konsentrasi fungisida maka semakin efektif dalam menghambat pertumbuhan penyakit pada tanaman. Begitu juga dengan hasil penelitian Ignatius Yuliantono (2002) bahwa fungisida berbahan aktif mankozeb
80 WP mampu menekan serangan penyakit daun akibat $P$ infestans dengan konsentrasi $3 \mathrm{~g} / \mathrm{l}$ dengan hasil tertinggi $8.4 \mathrm{t} / \mathrm{ha}$.

Tabel 2. Efektivitas Fungisida Mankozeb $80 \%$ terhadap serangan P.infestans di Sumberbrantas Batu pada Musim Hujan 2017

\begin{tabular}{|c|c|c|c|c|c|c|c|}
\hline \multirow{2}{*}{$\begin{array}{c}\text { Perlakuan } \\
\text { Konsentrasi } \\
\text { Mankozeb }\end{array}$} & \multicolumn{5}{|c|}{ Tingkat Efikasi Fungisida (\%) } & \multirow{2}{*}{$\begin{array}{l}\text { Rerata } \\
\text { Efektiv } \\
\text { itas (X) }\end{array}$} & \multirow{2}{*}{$\begin{array}{c}\text { Kategori } \\
\text { Efektifitas }\end{array}$} \\
\hline & 1 & 2 & 3 & 4 & 5 & & \\
\hline a. $4 \mathrm{~g} / \mathrm{l}$ & 50 & 82 & 87 & 83 & 87 & 78 & Efektif \\
\hline b. $3 \mathrm{~g} / \mathrm{l}$ & 71 & 65 & 70 & 66 & 61 & 67 & Efektif \\
\hline c. $2 \mathrm{~g} / 1$ & 52 & 36 & 61 & 47 & 57 & 51 & cukup efektif \\
\hline d. $1 \mathrm{~g} / \mathrm{l}$ & 49 & 23 & 37 & 16 & 36 & 32 & Kurang efektif \\
\hline e. Kontrol & 0 & 0 & 0 & 0 & 0 & 0 & Tidak efektif \\
\hline
\end{tabular}

Keterangan:

$0 \quad=$ tidak efektif

$>0-20 \%=$ sangat kurang efektif

$>20-40 \%=$ kurang efektif

$>40-60 \%=$ cukup efektif

$>60-80 \%=$ efektif

$>80 \%=$ sangat efektif (Irasakti dan Sukatsa, 1987)

Dari tabel 2 dapat dilihat bahwa perlakuan a dan $\mathrm{b}$ efektif dalam menekan $P$. infestans dengan rata-rata efektivitas sebesar $77,9 \%$ dan $66,58 \%$, sedangkan perlakuan c cukup efektif menekan P. infestans dengan reta-rata efektivitas sebesar $50,76 \%$ dan perlakuan d kurang efektif sebesar $32,17 \%$.

Rata-rata jumlah dan berat umbi kentang/tanaman dari 10 tanaman contoh disajikan pada Tabel 3. 
Tabel 3. Rerata produksi umbi kentang/tanaman dengan perlakuan fungisida di Sumberbrantas Batu pada musim hujan 2017

\begin{tabular}{lccc}
\hline \multirow{2}{*}{$\begin{array}{c}\text { Perlakuan } \\
\text { Konsentrasi }\end{array}$ Mankozeb } & \multicolumn{2}{c}{ Rerata Produksi } & \multirow{2}{*}{ Konversi ton/ha } \\
\cline { 2 - 3 } & $\begin{array}{c}\text { Kumlah } \\
\text { Umbi }\end{array}$ & $\begin{array}{c}\text { Berat Umbi } \\
\text { Kentang (kg) }\end{array}$ & \\
\hline a. $4 \mathrm{~g} / 1$ & $10,1 \mathrm{a}$ & $1,3 \mathrm{a}$ & 6,9 \\
b. $3 \mathrm{~g} / \mathrm{l}$ & $10,8 \mathrm{a}$ & $1,7 \mathrm{a}$ & 7,9 \\
c. $2 \mathrm{~g} / \mathrm{l}$ & $9,5 \mathrm{a}$ & $1,3 \mathrm{a}$ & 6,7 \\
d. $1 \mathrm{~g} / \mathrm{l}$ & $8,9 \mathrm{a}$ & $1,1 \mathrm{a}$ & 5,9 \\
e. Kontrol & $8,3 \mathrm{a}$ & $1,1 \mathrm{a}$ & 5,7 \\
\hline
\end{tabular}

Keterangan: Angka yang diikuti huruf yang sama pada kolom yang sama menunjukkan tidak berbeda nyata berdasarkan Uji BNJ dengan $\alpha=5 \%$

Pada Tabel 3, menunjukkan bahwa rerata produksi umbi kentang/tanaman menunjukkan bahwa jumlah umbi per tanaman antar perlakuan tidak berbeda nyata. Produksi kentang antar perlakuan tidak berbeda nyata, hal ini diduga akibat adanya serangan $P$. insfestans tidak begitu tinggi atau hanya menyerang daun sehingga tanaman kentang masih mampu berproduksi untuk membentuk umbi.

\section{Hasil Pengamatan Lokasi Nongkojajar Pasuruan}

Pengaruh konsentrasi fungisida Mankozeb 80 WP terhadap intensitas serangan $P$. Infestans disajikan pada Tabel 4.

Tabel 4. Intensitas Serangan Phythopthora infestans (\%) di Nongkojajar Pasuruan pada Musim Hujan 2018

\begin{tabular}{|c|c|c|c|c|c|}
\hline \multirow{2}{*}{$\begin{array}{l}\text { Perlakuan } \\
\text { Konsentrasi } \\
\text { Mankozeb }\end{array}$} & \multicolumn{5}{|c|}{$\begin{array}{c}\text { Intensitas Serangan } P \text {. infestans }(\%) \\
\text { Hari Setelah Tanam (HST) }\end{array}$} \\
\hline & $21 \mathrm{hst}$ & $28 \mathrm{hst}$ & $35 \mathrm{hst}$ & $42 \mathrm{hst}$ & $49 \mathrm{hst}$ \\
\hline a. $4 \mathrm{~g} / \mathrm{l}$ & $18,0 \mathrm{a}$ & $24,6 \mathrm{a}$ & $27,3 \mathrm{a}$ & $30,0 \mathrm{a}$ & $47,3 \mathrm{a}$ \\
\hline b. $3 \mathrm{~g} / 1$ & $28,6 \mathrm{ab}$ & $38,6 \mathrm{~b}$ & $30,6 \mathrm{a}$ & $48,6 a b$ & $60,6 \mathrm{ab}$ \\
\hline c. $2 \mathrm{~g} / 1$ & $28,6 \mathrm{ab}$ & $34,6 \mathrm{bc}$ & $33,3 \mathrm{a}$ & $59,9 \mathrm{bc}$ & $67,3 \mathrm{ab}$ \\
\hline d. $1 \mathrm{~g} / 1$ & $26,0 \mathrm{bc}$ & $44,0 \mathrm{~b}$ & $39,3 \mathrm{a}$ & $80,0 \mathrm{~cd}$ & $82,7 \mathrm{bc}$ \\
\hline E. Kontrol & $51,4 \mathrm{c}$ & $68,6 \mathrm{c}$ & $70,0 \mathrm{~b}$ & $90,0 \mathrm{~d}$ & $98,1 \mathrm{c}$ \\
\hline
\end{tabular}

Keterangan: Angka yang diikuti huruf yang sama pada kolom yang sama menunjukkan tidak berbeda nyata berdasarkan Uji BNJ dengan $\alpha=5 \%$

Dari Tabel 4. dapat dilhat bahwa perkembangbiakan penyakit yang diakibatkan oleh $P$. infestans sangat cepat dari awal sampai akhir pengamatan. Pada saat pengamatan umur 21 dan 28 HST semua 
perlakuan tidak berbeda nyata dengan kontrol. Selanjutnya pada pengamatan umur 35 sampai 49 HST pada perlakuan a walaupun berbeda nyata dengan perlakuan lainnya namun serangannya tetap tinggi dan selalu meningkat. Tingginya intensitas serangan $P$. infestans di Nongkojajar dikarenakan intensitas curah hujannya cukup tinggi terjadi setiap hari sehingga fungisida yang diberikan banyak yang tercuci, akibatnya dalam hitungan hari seluruh pertanaman kentang menjadi rusak (Gambar 3).

Menurut Winarto (1997), tingkat kerusakan tanaman oleh $P$. infestans, dipengaruhi oleh aspek curah hujan sehingga berpengaruh terhadap pemencaran patogen dan proses infeksi penyakit. Infeksi terjadi selama 72 jam setelah menempelnya konidium pada tanaman dan masa inkubasi terjadi 56 hari setelah proses infeksi. Selain curah hujan, perubahan cuaca tropika akhir-akhir ini menyebabkan terjadinya eskalasi dan peningkatan status penyakit tanaman yang dulunya minor menjadi penting dan makin merugikan (Wiyono, 2007)

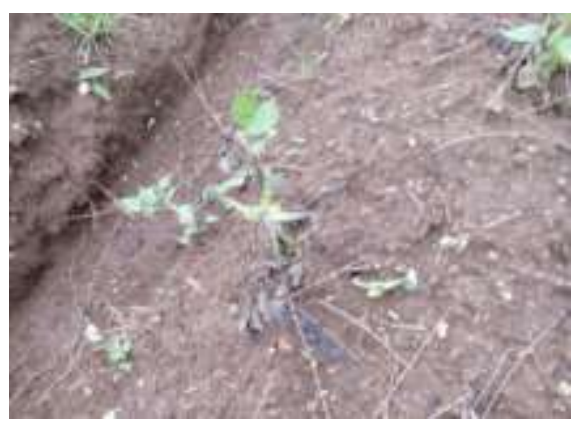

Gambar 3. Gejala serangan P. infestans pada kentang di Nongkojajar

Tabel 5. Efektifitas Fungisida berbahan aktif mankozeb $80 \%$ terhadap serangan $P$. infestans di Nongkojajar Pasuruan pada Musim Hujan 2018

\begin{tabular}{|c|c|c|c|c|c|c|c|}
\hline \multirow{2}{*}{$\begin{array}{l}\text { Perlakuan } \\
\text { Konsentrasi } \\
\text { Mankozeb }\end{array}$} & \multicolumn{5}{|c|}{ Tingkat Efikasi Fungisida (\%) } & \multirow{2}{*}{$\begin{array}{c}\text { Rerata } \\
\text { Efektifitas } \\
\text { (X) }\end{array}$} & \multirow{2}{*}{$\begin{array}{c}\text { Kategori } \\
\text { Efektifitas }\end{array}$} \\
\hline & 1 & 2 & 3 & 4 & 5 & & \\
\hline a. $4 \mathrm{~g} / \mathrm{l}$ & 65,0 & 63,8 & 61,0 & 66,7 & 51,8 & 61,7 & Efektif \\
\hline b. $3 \mathrm{~g} / \mathrm{l}$ & 44,3 & 43,7 & 56,2 & 46,0 & 38,2 & 45,7 & Cukup Efektif \\
\hline c. $2 \mathrm{~g} / \mathrm{l}$ & 44,3 & 49,5 & 52,4 & 33.4 & 31,3 & 42,2 & Cukup Efektik \\
\hline d. $1 \mathrm{~g} / \mathrm{l}$ & 35,2 & 35,9 & 43,8 & 11,1 & 15,6 & 28,3 & Kurang Efektif \\
\hline e. Kontrol & 0,0 & 0,0 & 0,0 & 0,0 & 0,0 & 0,0 & Tidak Efektif \\
\hline \multicolumn{8}{|c|}{ Keterangan: } \\
\hline \multicolumn{8}{|c|}{$0 \quad=$ tidak efektif } \\
\hline \multicolumn{8}{|c|}{$>0-20 \%=$ sangat kurang efektif } \\
\hline \multicolumn{8}{|c|}{$>20-40 \%=$ kurang efektif } \\
\hline \multicolumn{8}{|c|}{$>40-60 \%=$ cukup efektif } \\
\hline \multicolumn{8}{|c|}{$>60-80 \%=$ efektif } \\
\hline$>80 \%=$ sang & ktif & $\mathrm{kti}$ & Suka & 987) & & & \\
\hline
\end{tabular}


Tabel 6. Rerata produksi umbi kentang per tanaman dengan perlakuan fungisida di Nongkojajar Pasuruan pada Musim Hujan 2018

\begin{tabular}{|c|c|c|c|}
\hline \multirow{2}{*}{$\begin{array}{c}\text { Perlakuan } \\
\text { Konsentrasi } \\
\text { Mankozeb }\end{array}$} & \multicolumn{2}{|c|}{ Rerata Produksi Kentang/tanaman } & \multirow[b]{2}{*}{ Konversi ton/ha } \\
\hline & $\begin{array}{l}\text { Jumlah Umbi } \\
\text { (buah) }\end{array}$ & $\begin{array}{l}\text { Berat Umbi } \\
\text { Kentang (kg) }\end{array}$ & \\
\hline a. $4 \mathrm{~g} / 1$ & $16,0 \mathrm{a}$ & $1,3 \mathrm{a}$ & 6,0 \\
\hline b. $3 \mathrm{~g} / \mathrm{l}$ & $21,8 \mathrm{a}$ & $1,1 \mathrm{a}$ & 5,1 \\
\hline c. $2 \mathrm{~g} / 1$ & $17,8 \mathrm{a}$ & $1,2 \mathrm{a}$ & 5,5 \\
\hline d. $1 \mathrm{~g} / \mathrm{l}$ & $15,8 \mathrm{a}$ & $1,1 \mathrm{a}$ & 4,9 \\
\hline e. Kontrol & $21,6 \mathrm{a}$ & $1,0 \mathrm{a}$ & 4,3 \\
\hline
\end{tabular}

Keterangan: Angka yang diikuti huruf yang sama pada kolom yang sama menunjukkan tidak berbeda nyata berdasarkan Uji BNJ pada $\alpha=5 \%$.

Pada Tabel 6, menunjukkan bahwa rerata produksi umbi kentang/ tanaman menunjukkan bahwa jumlah umbi/tanaman antar perlakuan tidak berbeda nyata. Pada perlakuan $b$ jumlah umbi banyak tetapi ukuran umbinya kecil, sedangkan pada perlakuan a jumlah umbi sedikit tetapi ukuran umbinya besar sehingga berat umbinya paling tinggi di antara perlakuan.

\section{KESIMPULAN DAN SARAN}

\section{Kesimpulan}

Di Sumberbrantas-Batu, Mankozeb $80 \% \quad 4 \quad \mathrm{~g} / \mathrm{l}$ dan $3 \mathrm{~g} / \mathrm{l}$ efektif menekan penyakit hawar daun kentang akibat $P$. insfestans dengan kemampuan menekan serangan masing-masing sebesar $77,99 \%$ dan 66,578\%. Produksi kentang berturut-turut adalah 6,9 ton/ha dan 7,9 ton/ha.

Di Nongkojajar-Pasuruan, Mankozeb 80 WP 4 g/l efektif, sedangkan konsentrasi $3 \mathrm{~g} / \mathrm{l}$ dan $2 \mathrm{~g} / \mathrm{l}$ cukup efektif dengan kemampuan menekan serangan $P$. infestans berturut-turut sebesar 61,65\%, $45,68 \%$ dan 42.18\%. Produksi kentang berturut-turut sebesar 6,03 ton/ha; 5,13 ton/ha dan 5,49 ton/ha.

Selama percobaan tidak terdapat tanda-tanda fitotoksis pada daun tanaman kentang.

\section{Saran}

Perlu diteliti perhitungan usahatani pada masing-masing perlakuan untuk menentukan perlakuan terbaik. 


\section{UCAPAN TERIMA KASIH}

Ucapan terima kasih dan penghargaan disampaikan kepada bapak Sarwono dan Supriyanto yang telah banyak membantu dalam pelaksanaan di lapang.

\section{DAFTAR PUSTAKA}

BPS (Badan Pusat Statistik). 2009. Luas panen, Produksi dan Produktivitas Kentang, 2009-2011.

http://www.bps.go.id. diakses 16 Desember 2016.

Correa, R.M., J.E.B.P. Pinto, C.A.B.P. Pinto, V. Faquin, E. Reis, A.B. Monteiro, W.E. Dyer. 2008. A comparison of potato seed tuber yields in beds, post and hydroponic systems. Sci Hort. 116:17-20.

Dinar, A., P. Agus, Herman, Suryaningsih, dan A. Hajrial. 2011. Efikasi Gen RB pada Tanaman Kentang Transgenik Katahdin SP 904 dan SP951 terhadap Empat Isolat Phytopthora infestans dari Jawa Barat. Jurnal AgroBiogen 7(1): 28-36.

Hanm, P.B. 2007. The Canon of Potato Science:9. Soil-Borne Fungi. Potato Pres 50: 239241. Doi 10.1007/S.11540008-0904.x (26 Juni 2010).

Irasakti, L. dan Sukatsa. 1987. Uji kemempanan beberapa fungisida terhadap penyakit bercak coklat pada tanaman padi. Gatra Penelitian Penyakit
Tumbuhan dalam Pengendalian Secara Terpadu. PFI. Surabaya. 24-26 Nopember. Hal. 55-70.

Jeger, M.J., G.A. Nide, P.H.J.F. Van den Boosert, A.J. Termorshuizen and P. Van. Baarlen. 1996. Pathology and Control of Soilborne Fungal Pathogen of Potato. Potato pes. 39 :437-469.

Priou, S., A.P. Aley, E. Chujoy, B. Lemaga, and E. Frenh. 2011. Integrated Control of Bacterial Wilt of Potato. http://www.cipotato.org/csd/m aterials/Publications/guiaing.pdf diakses 3 Januari 2017.

Puslitbang Hortikultura. 2008. Pengembangan Varietas Kentang Prosesing mendukung Industri Potato Chips di Indonesia. Bahan Pers Release. Puslitbang Hortikultura. Jakarta.

Semangun, H. 2000. PenyakitPenyakit Tanaman Hortikultura di Indonesia. Gadjah Mada University Press. Yogyakarta.

Semangun, H. 2006. Pengantar Ilmu Penyakit Tumbuhan. Gadjah Mada. University Press, Yogyakarta.

Sugama, I.W. dan A. Rochjadi. 1989. Kemempanan beberapa fungisida menekan serangan jamur Hemileia vastatrix Berk \& Br. pada tanaman kopi arabica. Prosiding Kongres Nasional X dan Seminar PFI, Bali. Hal. 415-416. 
Suhardi. 2007. Efektivitas Fungisida untuk Pengendalian penyakit berdasarkan Curah Hujan Pada mawar. Balai Penelitian Tanaman Hias. Cianjur 17(4): 355-364.

Winarto. 1997. Studi Keragaman Gejala, Morfologi, Patogenitas dan Intensitas Penyakit Tanaman. Prosiding kongres dan Seminar PFI XIV. Volume II. 338-345.

Wiyono, S. 2007. Perubahan Iklim dan Ledakan Hama dan Penyakit Tanaman. Makalah pada Seminar Keanekaragaman Hayati di Tengah Perubahan Iklim : Tantangan Masa depan Indonesia. KEHATI. Jakarta 28 Juni 2007. 